\title{
PERANAN BAITUL MAAL WA TAMWIL MENINGKATKAN USAHA MIKRO MELALUI PEMBIAYAAN MUDHARABAH
}

\section{THE ROLE OF BAITUL MAAL WA TAMWIL INCREASE MICRO ENTERPRISE FUNDING THROUGH MUDHARABAH}

\author{
R.A Y Prasetya1, dan S. Herianingrum²
}

\begin{abstract}
1Program Studi S1 Ekonomi Islam-Fakultas Ekonomi dan Bisnis-Universitas Airlangga, Email: agungrenatha@gmail.com

${ }^{2}$ Departemen Ekonomi Syariah-Fakultas Ekonomi dan Bisnis-Universitas Airlangga, Email : sriheria@yahoo.co.id
\end{abstract}

\begin{abstract}
Micro enterprise is one of the biggest economic pillar for Indonesians, with capital problem as its biggest threat for any micro enterpreneur who wants to develop their business further. Baitull Maal wat Tamwil can be the alternative solution for micro enterpreneur who needs some capital assistance which free from riba, collateral, and easy to access. This research is a qualitative research with study case as its core. Narrative descriptive was used to explain the role of Baitul Maal wat Tamwil in the enhancement of micro enterprise which based on development in the business aset, business revenue, business profit, and business stability through mudharabah financial system. Representation and time are the two indicator which was used to choose 10 key respondent, from the people who have used Mudharabah Mikro product in BMT Asy-Syifa, Sidoarjo. This research result in finding that BMT have the important role for enhancing the micro enterprise of its customer.
\end{abstract}

Keywords: Micro Enterprise, Mudharabah, Baitul Maal wa Tamwil, Business Enhancement

\section{ABSTRAK}

Perusahaan mikro adalah salah satu pilar ekonomi terbesar bagi Indonesia, masalah modal menjadi ancaman terbesar bagi setiap pengusaha mikro yang ingin mengembangkan bisnis mereka lebih lanjut. Baitul Maal wa Tamwil dapat menjadi solusi alternatif bagi pengusaha mikro yang membutuhkan beberapa bantuan modal yang bebas dari riba, agunan, dan mudah. Penelitian ini adalah penelitian kualitatif dengan studi kasus sebagai intinya. Deskriptif naratif digunakan untuk menjelaskan peran Baitul Maal wat Tamwil dalam peningkatan usaha mikro yang berbasis pada pengembangan di aset bisnis, pendapatan bisnis, laba usaha, dan stabilitas bisnis melalui sistem keuangan mudharabah. Representasi dan waktu adalah dua indikator yang digunakan untuk memilih 10 responden kunci, dari orang-orang yang telah menggunakan produk Mudharabah Mikro di BMT Asy-Syifa, Sidoarjo. Hasil penelitian menemukan bahwa BMT memiliki peran penting untuk meningkatkan usaha mikro dari pelanggan.

Keyword: Perusahaan Mikro. Mudharabah, Baitul Maal Wa Tamwil, Peningkatan Bisnis.

Prasetya, Renata A Y. 2016. Peranan Baitul Maal Wa Tamwil Meningkatkan Usaha Mikro Melalui Pembiayaan Mudharabah. Jurnal Syarikah 2 (2). Hal. 252-267 


\section{PENDAHULUAN}

Falah adalah suatu puncak kebahagiaan yang dirasakan oleh seorang muslim, kebahagiaan tersebut dapat dicapai saat seorang muslim memperoleh kesejahteraan hidup baik di dunia maupun di akhirat dengan mengikuti ketentuan-ketentuan yang telah digariskan syariat Islam (Hidayat, 2010:219). Dapat disimpulkan bahwa kesejahteraan hidup di dunia merupakan salah satu ciri dan elemen bagi seorang muslim yang dapat dijadikan sebagai indikator tercapainya falah.

Indonesia sebagai negara dengan jumlah penduduk muslim terbesar di dunia tidak terlepas usaha masyarakatnya untuk mencari rizki, utamanya pada sektor produksi yang saat ini banyak didominasi oleh kegiatan wirausaha dalam kelompok usaha mikro. Lebih dari 98\% usaha yang ada di Indonesia terdiri atas usaha mikro (depkop.go.id).

Namun sebagai salah satu sektor yang menopang banyak kehidupan masyarakat Indonesia, kegiatan usaha mikro hingga saat ini banyak terhambat oleh masalah. Utamanya masalah keterbatasan modal, dengan angka lebih dari 950.000 unit usaha mikro yang mengalaminya pada tahun 2013 (BPS, 2013).

Peran pemerintah serta lembaga keuangan seperti bank sangat diperlukan untuk mengatasi masalah keterbatasan modal. Namun dalam praktiknya, menurut Ashari sebagaimana dikutip Khaeli (2012:8) masih banyak bank umum yang kurang antusias dalam kegiatan-kegiatan pembiayaan serta penyaluran kredit ke usaha-usaha kecil serta mikro.

Praktek tersebut disebabkan oleh, pengalaman atas banyaknya kredit macet dan bermasalah saat diselenggarakan program Kredit Usaha Rakyat, aturan Bank Indonesia yang ketat agar bank umum lebih prudent dalam pembiayaan, serta kurangnya pengalaman beberapa bank umum dalam menyalurkan kredit ke usaha-usaha kecil dan mikro.

Di sisi lain, sistem pembiayaan dengan seluruh instrumen yang digunakan oleh bank umum juga memberikan pengaruh yang signifikan bagi terjadinya disintermediasi sistem keuangan. Sistem bunga dan agunan yang ditetapkan bagi nasabah yang mengajukan permintaan kredit kepada bank umum merupakan sebuah ketidakadilan, karena mekanisme penetapan profit yang hanya menguntungkan salah satu pihak saja dengan menetapkan biaya modal mendahului proses pengelolaan modal tanpa mengetahui bagaimana hasil usaha yang didapatkan oleh debitur di masa depan (Diola, 2011:2).

Salah satu solusi dari persoalan tersebut adalah dengan menyediakan pembiayaan bagi usaha mikro melalui berbagai instrumen pembiayaan mikro bebas bunga, salah satunya adalah melalui BMT. Pembiayaan BMT selalu menggunakan berbagai akad syariah dalam memenuhi fungsinya sebagai lembaga intermediasi keuangan mikro, serta lebih banyak menggunakan akadakad yang bergerak langsung di sektor riil.

Salah satu instrumen pembiayaan yang terdapat dalam BMT adalah mudharabah. Mudharabah diartikan 
sebagai akad kerjasama usaha antara shahibul maal (pemilik dana) dan mudharib (pengelola dana) dengan nisbah bagi hasil menurut kesepakatan di muka (PSAK No.59, par:6). Dalam kegiatan pembiayaan yang dilakukan oleh BMT, BMT berposisi sebagai shahibul maal yang memberikan $100 \%$ dana modal kepada usaha mikro sebagai mudharib. Dalam pelaksanaan usahanya, jika terjadi kerugian, BMT akan menanggung kerugian tersebut kecuali jika kerugian disebabkan oleh kelalaian dari pihak mudharib (PSAK No.59, par:7). BMT Asy Syifa merupakan salah satu BMT yang berfokus pada pembiayaan mikro berbasis syariah. Salah satu produk pembiayaan unggulan dari BMT Asy Syifa adalah pembiayaan mudharabah mikro. Pembiayaan ini memiliki perbedaan dengan mudharabah biasa, terutama jika ditinjau dari sisi administratif, dimana masyarakat dapat mengajukan permohonan dana pada produk pembiayaan ini tanpa melalui proses yang sangat rumit sehingga siapapun termasuk pemilik UMK dapat mengaksesnya dengan mudah.

\section{MATERI DAN METODE}

Baitul maal wat tamwil (BMT) terdiri atas dua pengertian yaitu baitul maal dan baitut tamwil (Falihah, 2007:30). Baitul maal adalah lembaga keuangan yang mengelola dana bersifat nirlaba (sosial) seperti zakat, infaq, shadaqah, maupun wakaf serta mengatur distribusinya sesuai dengan yang telah diamanahkan serta disyariatkan dalam Islam. Sedangkan baitul tamwil adalah lembaga keuangan yang berfungsi sebagai intermediasi keuangan untuk menyalurkan dana masyarakat dengan berlandaskan pada profit motive.

Fungsi dan peran BMT sebagaimana dijelaskan oleh Buchori dalam Rahmi (2011:22) sebagai berikut:

1. Manajer investasi, yang dimaksud adalah bahwa BMT dapat memainkan perannya sebagai agen atau sebagai penghubung bagi para pemilik dan dan menyalurkan dan yang telah terkumpul pada calon atau anggota yang telah ditunjuk oleh pemilik dana.

2. Investor, BMT memiliki peran sebagai investor jika BMT memperoleh dana dari pihak yang mempercayakan pengelolaan dananya secara utuh kepada BMT yang bersangkutan.

3. Sosial, BMT diharuskan mampu memberikan pelayanan sosial baik kepada anggota yang membutuhkan maupun kepada masyarakat dhuafa.

Kata pembiayaan berasal dari kata biaya yang dapat diartikan pengeluaran atau pengorbanan yang tidak dapat dihindarkan untuk mendapatkan suatu barang atau jasa dengan tujuan memperoleh maslahat, pengeluaran untuk suatu kegiatan, tujuan, atau waktu tertentu, seperti ongkos pengiriman, packaging, dan penjualan yang dimaksudkan untuk memperoleh penghasilan dalam laporan laba rugi perusahaan (Suhendri, 2011:24).

Pembiayaan merupakan salah satu tugas pokok bank, yaitu pemberian fasilitas penyediaan dana untuk memenuhi kebutuhan pihak-pihak yang merupakan deficit unit (Karim dalam Syafi'i, 2009: 160). Dan menurut sifat penggunaannya, pembiayaan dapat dibagi menjadi dua: 
a. Pembiayaan produktif, yaitu pembiayaan yang ditujukan untuk memenuhi kebutuhan produksi dalam arti luas, yaitu untuk peningkatan usaha, baik usaha produksi, perdagangan, maupun investasi.

b. Pembiayaan konsumtif, yaitu pembiayaan yang digunakan untuk memenuhi kebutuhan konsumsi, yang akan habis digunakan untuk memenuhi kebutuhan.

Ditinjau dari ada atau tidaknya kompensasi dalam sebuah pembiayaan, fiqh muamalah dalam Islam membagi akad pembiayaan menjadi dua jenis, yaitu akad tijarah dan akad tabarru' (Karim, 2011: 66).

Karim (2011:70) menjelaskan bahwa akad tijarah adalah segala macam perjanjian yang menyangkut for profit transaction. Akad-akad ini dilakukan dengan tujuan mencari keuntungan, karena itu bersifat komersil. Berdasarkan tingkat kepastian dari hasil yang diperolehnya, akad tijarah dapat dibagi menjadi dua kelompok besar yakni:

\section{a. Natural Uncertainty Contract}

Dalam Natural Uncertainty Contract, pihak-pihak yang bertransaksi saling mencampurkan asetnya (baik real aset maupun financial aset) menjadi satu kesatuan dan kemudian menanggung risiko bersama-sama untuk mendapatkan keuntungan. Contoh-contoh transaksi ini adalah Musyarakah, Muzara'ah, Musaqah, Mukhabarah.

b. Natural Certainty Contract

Dalam Natural Certainty Contract, kedua belah pihak saling mempertukarkan aset yang dimilikinya karena itu objek pertukarannya. Yang termasuk dalam kategori ini adalah kontrak jual beli (Al Bai' naqdan, al Bai' Muajjal, al Bai' Taqsith, Salam, Istishna), sewa-menyewa (Ijarah dan Ijarah Muntahia bittamlik).

Akad tabarru' (gratuitos contract) adalah segala macam perjanjian yang menyangkut non profit transaction (transaksi nirlaba). Transaksi ini pada hakikatnya bukan transaksi bisnis untuk mencari keuntungan komersil (Karim, 2011: 66).

Akad tabarru' dilakukan dengan tujuan tolong menolong dalam rangka berbuat kebaikan (tabarru' berasal dari kata birr dalam bahasa arab, yang artinya kebaikan. Dalam akad tabarru', pihak yang berbuat kebaikan tersebut tidak berhak mensyaratkan imbalan apapun kepada pihak lainnya. Imbalan dari akad tabarru' adalah dari Allah SWT bukan dari manusia.

Contoh akad-akad tabarru adalah qardh, rahn, hiwalah, wakalah, kafalah, wadi'ah, hibah, waqf, shadaqah, hadiah, dan lain-lain (Karim: 2011,70). Mudharabah atau qiradh termasuk dalam kategori syirkah. Dalam bahasa irak digunakan kata mudharabah, sedangkan penduduk Hijaz menyebutnya qiradh. Di dalam Al Quran, kata mudharabah tidak disebutkan secara jelas dengan istilah mudharabah. Al Quran hanya menyebutkannya secara tersirat dari kata dharaba (Huda, 2010:71).

Kata mudharabah berasal dari kata dharb yang berarti memukul atau berjalan. Makna memukul atau berjalan ini lebih tepat secara istilah diartikan sebagai seseorang yang memukulkan kakinya dalam menjalankan usaha (Syafi'i, 2009:95).

Secara global dapat ditarik sebuah kesimpulan bahwa pengertian 
mudharabah adalah kerjasama usaha antara dua pihak, pihak pertama merupakan pihak pemilik dana (shahibul maal) yang menyediakan seluruh (100\%) modal, sedangkan pihak lainnya menjadi pengelola (mudharib). Keuntungan usaha secara mudharabah dibagi menurut kesepakatan yang telah dituangkan dalam kontrak, sedangkan apabila mengalami rugi, kerugian tersebut akan ditanggung oleh pemilik dana selama kerugian tersebut tidak disebabkan oleh kelalaian pengelola dana. Jika kelalaian tersebut disebabkan oleh kecurangan atau kelalaian dari pengelola dana, maka pengelola wajib bertanggung jawab atas kerugian tersebut. (Syafi'i, 2009:95)

Mudharabah secara garis besar dapat dikelompokan atas dua bagian besar, (Huda 2010:77) yaitu:

a. Mudharabah muqayyadah, yaitu akad mudharabah dimana shahibul maal membatasi jenis usaha, waktu dan tempat usaha yang akan dijalankan oleh pengelola dana.

b. Mudharabah muthlaqah, yaitu bentuk kerjasama antara shahibul maal dan mudharib yang cakupannya sangat luas dan tidak dibatasi oleh spesifikasi jenis usaha dan waktu daerah berbisnis.

Usaha mikro adalah usaha yang membutuhkan modal yang relatif kecil sehingga usaha mikro lebih fleksibel dalam beradaptasi dengan perubahan pasar.

Usaha mikro memiliki definisi yang berbeda ditiap wilayah, khususnya ditiap negara. Perbedaan definisi tersebut dikarenakan tiap negara memiliki indikator yang berbeda untuk menentukan apakah sebuah usaha dapat dikategorikan sebagai usaha mikro.
Indikator yang banyak digunakan untuk menentukan hal tersebut adalah jumlah karyawan, jumlah aset, dan jumlah pendapatan.

Undang-Undang Nomor 20 Tahun 2008 tentang UMK mendefinisikan usaha mikro sebagai usaha produktif milik orang perorangan dan atau badan usaha perorangan yang memenuhi kriteria aset kurang dari atau sama dengan $\mathrm{Rp}$. 50.000.000 dan omzet kurang dari atau sama dengan Rp 300.000.000. Usaha kecil adalah usaha ekonomi produktif yang berdiri sendiri, yang dilakukan oleh orang perorangan/badan usaha yang bukan merupakan anak perusahaan/bukan cabang perusahaan yang dimiliki bagian baik langsung maupun tidak langsung dari usaha menengah atau usaha besar.

Berdasarkan Kamus besar Bahasa Indonesia, meningkat memiliki arti bertambahnya suatu nilai menjadi lebih tinggi, atau dapat dikatakan juga berubahnya keadaan dari sesuatu yang sebelumnya rendah menjadi lebih tinggi. Sedangkan peningkatan sendiri dapat dimaknai proses dari sesuatu yang sebelumnya memiliki nilai yang rendah, menjadi memiliki nilai yang tinggi.

Falihah (2007: 52) menyatakan bahwa pemberdayaan adalah suatu usaha mencegah terjadinya persaingan yang tak seimbang melalui upaya peningkatan nilai. Terdapat 4 indikator peningkatan usaha dalam penelitian ini, yaitu:

1. Aset perusahaan

Sholihin (2010: 103) menjelaskan bahwa aset adalah segala hal dalam perusahaan yang dapat dimanfaatkan untuk kegiatan produksi, membuat aliran kas menjadi positif, maupun manfaat ekonomi lainnya sebagai 
bagian dari transaksi atau peristiwa masa lalu.

2. Penjualan atau omzet

Menurut Chaniago (1995:14) omzet penjualan adalah keseluruhan jumlah pendapatan yang didapat dari hasil penjualan suatu barang atau jasa dalam kurun waktu tertentu.

3. Pendapatan

Pendapatan didefinisikan Sholihin (2010: 621) sebagai suatu kenaikan kotor dalam aset atau penurunan dalam liabilitas atau gabungan keduanya selama periode tertentu yang diperoleh dari investasi, jasa, perdagangan, atau aktivitas lain yang halal dan bertujuan untuk meraih keuntungan.

4. Stabilitas usaha

Munawir (2000: 31) mengartikan stabilitas usaha sebagai kemampuan perusahaan untuk melakukan usahanya dengan stabil, yang diukur dengan mempertimbangkan kemampuan perusahaan untuk membayar kewajiban atas hutanghutangnya termasuk tepat pada waktunya serta kemampuan menjalankan usahanya secara berkelanjutan tanpa mengalami hambatan atau krisis keuangan.

BMT merupakan lembaga keuangan mikro yang memiliki berbagai produk pembiayaan berbasis syariah. Akad pembiayaan sendiri dalam Islam terdiri atas dua bagian sebagaimana dijelaskan oleh Karim (2011: 66) yaitu akad tabarru dan tijarah.

Akad tijarah merupakan akad dengan orientasi bisnis yang tujuan utamanya adalah mendapatkan return dalam setiap pembiayaan. Akad tijarah juga dapat dibagi dalam dua kelompok besar, yaitu certainly contract dengan return pasti yang telah disepakati di awal, serta uncertainly contract dengan return tidak pasti dan mendasarkan jumlahnya pada banyaknya profit yang didapatkan dalam usaha. Mudharabah, merupakan salah satu akad pembiayaan yang memiliki potensi peran yang besar dalam pembiayaan usaha mikro, utamanya produk pembiayaan mudharabah muqayyadah. Pembiayaan muqayyadah ini diberikan kepada pemilik UKM dengan harapan membantu mereka untuk semakin meningkatkan usahanya.

Untuk mengetahui terjadinya peningkatan usaha dari suatu usaha mikro yang memperoleh pembiayaan mudharabah tersebut diperlukan indikator. Indikator yang digunakan sebagai tolok ukur untuk mengetahui peningkatan usaha tersebut adalah aset, penjualan/omzet, pendapatan, dan stabilitas usaha. Apabila terdapat kenaikan minimal salah satu dari keempat aspek tersebut, maka usaha tersebut dapat dikatakan meningkat, sehingga dapat dikatakan bahwa pembiayaan mudharabah yang diberikan berperan dalam peningkatan usaha mikro. Sebaliknya, jika dalam indikator tersebut tidak terdapat satupun peningkatan, maka dapat dikatakan bahwa usaha tersebut tidak meningkat, dapat ditarik kesimpulan bahwa pembiayaan mudharabah yang diberikan tidak berperan dalam peningkatan usaha mikro.

\section{Pendekatan Penelitian}

Pendekatan yang digunakan dalam penelitian ini adalah pendekatan kualitatif deskriptif. Pendekatan kualitatif adalah pendekatan dengan menggunakan data yang berupa kalimat tertulis atau 
lisan, peristiwa-peristiwa, pengetahuan, atau proyek studi yang bersifat deskriptif (Nazir, 2005: 54). Sedangkan pendekatan deskriptif digunakan untuk menggambarkan suatu realitas gejala sosial yang tengah terjadi saat dilakukan penelitian. Pendekatan kualitatif digunakan dalam penelitian ini, karena dibutuhkan suatu metode untuk menggambarkan realitas yang terjadi di lapangan pada saat ini.

Strategi yang digunakan dalam penelitian ini adalah studi kasus, sebagaimana yang telah diungkapkan oleh Yin (2012:4-8) bahwa strategi ini tepat digunakan dalam penelitian dengan basis pertanyaan "bagaimana". Di samping itu, dengan tujuan penggambaran realitas lapangan, maka penggunaan studi kasus juga sangat relevan mengingat hasil penelitian dengan studi kasus sangat sulit untuk dimanipulasi, dikarenakan tidak ada peluang bagi peneliti untuk mengontrol peristiwa-peristiwa yang akan terjadi.

\section{Ruang Lingkup Penelitian}

Peneliti membatasi ruang lingkup penelitian pada pembiayaan mudharabah mutlaqah saja. Pembiayaan mudharabah mutlaqah yang yang termasuk dalam ruang lingkup ini adalah produk pembiayaan mudharabah dari BMT Asy Syifa Kecamatan Taman Kabupaten Sidoarjo yang telah diberikan kepada para pengusaha mikro. Usaha mikro yang dipilih pun terbatas pada usaha mikro yang menggunakan produk pembiayaan mudharabah mikro dari BMT Asy Syifa.

Kriteria peningkatan usaha yang dibahas dalam penelitian ini juga dibatasi pada empat aspek, yaitu dipandang dari sisi aset, omzet/ penjualan, pendapatan, serta stabilitas usaha. Keempat aspek tersebut dijadikan sebagai tolak ukur keberhasilan dari pembiayaan mudharabah oleh BMT Asy Syifa untuk meningkatkan usaha mikro milik masyarakat.

\section{Jenis dan Sumber Data}

Jenis data yang digunakan dalam penelitian ini adalah data primer dan data sekunder. Data primer adalah data yang didapatkan secara langsung di lapangan baik melalui wawancara maupun melakukan observasi kepada sumber data secara langsung. Sedangkan data sekunder adalah data yang diperoleh dari sumber kedua dari data yang dibutuhkan oleh peneliti, sehingga responden dengan peneliti tidak melakukan kontak secara langsung atau peneliti mengambil data dari peneliti lain (Bungin, 2005:128).

\section{Teknik Pemilihan Responden.}

Peneliti memperoleh responden dengan cara penggunaan indikator yakni teknik pemilihan responden sebagai sumber data dengan pertimbangan dan kriteria, atau syarat yang telah ditentukan. (Moleong, 2014:199)

Dalam penelitian ini, digunakan dua kelompok responden. Yang pertama adalah pihak manajerial dari BMT Asy Syifa Sidoarjo. Dari responden ini didapatkan informasi mengenai BMT, produk mudharabah mikro dan penerima dana mudharabah mikro di lapangan. Informasi dari pihak manajerial juga penting untuk nantinya digunakan sebagai acuan penentu keabsahan data dan informasi yang diterima oleh peneliti di lapangan.

Responden kedua adalah responden kunci, yaitu para pemilik usaha mikro yang menerima pembiayaan mudharabah mikro sebagai subjek penelitian ini. Dari responden ini, didapatkan secara 
langsung data-data tentang peran BMT dalam peningkatan usaha mereka melalui pembiayaan mudharabah mikro. Responden utama ini dipilih berdasarkan hasil diskusi dengan pihak manajerial.

Terdapat dua indikator dalam memilih responden kedua ini. Yang pertama adalah bahwa responden ini telah mengikuti program mudharabah mikro setidaknya selama satu tahun. Indikator ini digunakan dengan pertimbangan peran.

Indikator kedua adalah dengan pertimbangan keterwakilan. Peneliti akan memilih responden yang dapat mewakili berbagai jenis usaha dalam penerima dana mudharabah mikro ini tanpa hanya terfokus pada satu jenis usaha saja.

\section{Prinsip Pengumpulan Data}

Yin (2012:119) menyebutkan tiga prinsip pengumpulan data guna menunjang sumber bukti tersebut, yaitu:

a. Menggunakan multi sumber bukti

Multi sumber bukti digunakan agar dalam penelitian studi kasus hasilnya akan lebih relevan daripada menggunakan satu sumber bukti saja. Hal yang perlu diperhatikan dalam menggunakan multi sumber bukti yaitu triangulasi.

Teknik triangulasi yang digunakan dalam penelitian ini adalah triangulasi dengan metode. Triangulasi dengan metode menurut Moleong (2006:331) adalah pengecekan derajat kepercayaan penemuan hasil penelitian dengan beberapa teknik pengumpulan data.

b. Menciptakan data dasar studi kasus

Dasar dari prinsip ini adalah memisahkan data-data dokumen studi kasus yang didapat dari lapangan dengan hasil yang disajikan dalam laporan studi kasus itu sendiri. Hal ini dilakukan agar sumber data dalam dokumen studi kasus tetap terjaga.

c. Memelihara rangkaian bukti Rangkaian bukti yang dikumpulkan dalam studi kasus harus dijaga baik urutan tanggal maupun kejadian untuk menjaga reliabilitas informasi studi kasus.

\section{Teknik Analisis}

Teknik analisis dalam penelitian ini akan dilakukan dengan pendekatan kualitatif deskriptif dan menggunakan strategi studi kasus. Analisis yang digunakan adalah dengan cara membandingkan temuan di lapangan dengan preposisi yang telah dibuat sebelumnya (Yin: 2012: 136). Preposisi merupakan salah satu contoh dari dari orientasi teoritis yang menuntun analisis studi kasus. Sehingga preposisi yang dibuat dapat membantu penelitian untuk lebih terfokus, membantu memfokuskan perhatian pada data tertentu, dan memiliki urgensi untuk dibuktikan kebenarannya.

Metode yang digunakan dalam penelitian ini adalah explanasi, karena tujuan dalam penelitian ini adalah menjelaskan peran BMT dalam meningkatkan usaha mikro melalui pembiayaan mudharabah. Pembuatan eksplanasi dalam penelitian ini dilakukan dalam bentuk naratif deskriptif.

\section{HASIL DAN PEMBAHASAN}

\section{Gambaran Umum BMT Asy Syifa}

BMT Asy Syifa adalah salah satu lembaga keuangan mikro berbasis syariah yang berlokasi di Jalan Bebekan Tengah nomor 37 Taman Sepanjang, Kabupaten Sidoarjo. BMT Asy Syifa telah 
berdiri sejak awal 2013 dan diresmikan langsung oleh $\mathrm{H}$. Soekarwo selaku Gubernur Jawa Timur. Sebagai lembaga keuangan mikro syariah, BMT Asy Syifa telah mengeluarkan berbagai produk pembiayaan serta pendanaan dengan berbasis akad syariah seperti mudharabah, musyarakah, murabahah, wadiah, dan bai' bitsaman ajil. Sejak pertama berdiri hingga saat ini, BMT Asy Syifa telah melakukan pembiayaan secara total sebesar Rp. 2,2 milyar rupiah.

\section{Gambaran Produk Pembiayaan Mudharabah Mikro}

Pembiayaan mudharabah mikro adalah sub produk dari pembiayaan mudharabah yang ada di BMT Asy Syifa. Ide untuk produk pembiayaan ini sudah ada dan diperkenalkan ke masyarakat sejak tahun 2012, dan secara resmi menjadi salah satu produk pembiayaan BMT Asy Syifa sejak 2013.

Sesuai namanya, produk ini menggunakan akad mudharabah sebagai basis pembiayaannya, dan diperuntukkan hanya untuk usaha mikro. Produk Pembiayaan mudharabah mikro adalah pembiayaan dengan cicilan ringan yang dapat dilakukan per hari, serta margin bagi hasil yang ditentukan sendiri oleh nasabah pembiayaan berdasarkan keuntungan yang diperoleh dalam hari tersebut. Dengan sistem pembiayaan ini, maka pembiayaan syariah yang ideal dapat dilakukan, di mana shahibul maal (BMT) akan mengalami kerugian jika mudharib mengalami kerugian dalam usahanya, sehingga dapat terbangun rasa saling percaya dan mendukung antara BMT dengan nasabah pembiayaan.

Proses pengajuan pembiayaan mudharabah mikro cukup mudah, karena hanya diperlukan berkas-berkas seperti
KTP, KSK, dan wawancara singkat mengenai jenis dan riwayat usahanya. Pencairan dana dapat dilakukan dengan cukup cepat, sehingga produk ini cocok untuk nasabah yang membutuhkan pembiayaan produktif dalam waktu cepat.

Penelitian ini merupakan hasil wawancara terhadap dua belas orang responden yang ditemui oleh peneliti dalam masa penelitian. Responden pertama yang diwawancarai oleh peneliti merupakan pencetus produk mudharabah mikro pada BMT Asy Syifa Kabupaten Sidoarjo, sekaligus mantan manager BMT yang pertama kali menduduki jabatan tersebut saat BMT Asy Syifa pertama berdiri. Responden kedua merupakan manager yang saat ini menjabat di BMT Asy Syifa. Dan responden 3-12 merupakan pemilik usaha mikro sekaligus nasabah dari BMT Asy Syifa.

Identitas kedua belas responden tersebut yaitu: 
Tabel 1. Identitas dan karakteristik responden

\begin{tabular}{|c|c|c|}
\hline Responden & Nama & $\begin{array}{l}\text { Karakteristik } \\
\text { Responden }\end{array}$ \\
\hline 1 & $\begin{array}{l}\text { Ichlasul Amal } \\
\text { Rangga } \\
\text { Winata }\end{array}$ & $\begin{array}{l}\text { Pencetus produk } \\
\text { mudharabah mikro } \\
\text { di BMT Asy Syifa }\end{array}$ \\
\hline 2 & $\begin{array}{l}\text { Lukman Al } \\
\text { Hakim }\end{array}$ & $\begin{array}{l}\text { Manajer BMT Asy } \\
\text { Syifa }\end{array}$ \\
\hline 3 & Subaidah & Pedagang bandeng \\
\hline 4 & $\begin{array}{c}\text { Lilik } \\
\text { Chamidah }\end{array}$ & Pedagang nasi \\
\hline 5 & Siti Fatimah & Pedagang penyetan \\
\hline 6 & $\begin{array}{c}\text { Imam } \\
\text { Wahyudi }\end{array}$ & Pemilik percetakan \\
\hline 7 & Suyono & $\begin{array}{l}\text { Pemilik warung } \\
\text { kopi }\end{array}$ \\
\hline 8 & $\begin{array}{l}\text { Samiyah \& } \\
\text { Aan }\end{array}$ & $\begin{array}{c}\text { Pedagang krupuk \& } \\
\text { ayam }\end{array}$ \\
\hline 9 & Juminah & Pedagang kue \\
\hline 10 & Maslachah & $\begin{array}{c}\text { Pedagang gorengan } \\
\text { \& soto }\end{array}$ \\
\hline 11 & Suartini & Pedagang sembako \\
\hline 12 & Hj. Churiyah & Pemilik kos-kosan \\
\hline
\end{tabular}

Sumber: Data BMT Asy Syifa

Di bawah ini merupakan hasil analisis usaha dengan informasi dari wawancara 10 responden pemilik usaha mikro (responden 3-12) yang mendapatkan pembiayaan mudharabah mikro di BMT Asy Syifa Sidoarjo.

1. Aset Usaha

Sholihin (2010: 103) menjelaskan bahwa aset adalah segala hal dalam perusahaan yang dapat dimanfaatkan untuk kegiatan produksi, membuat aliran kas menjadi positif, maupun manfaat ekonomi lainnya sebagai bagian dari transaksi atau peristiwa masa lalu.

Dalam wawancara yang telah dilakukan dilapangan terhadap responden, maka ditemukan bahwa 8 dari 10 responden mengalami peningkatan dalam asetnya setelah mendapatkan pembiayaan mudharabah mikro. Sebagian besar responden menggunakan pinjaman modal yang diperolehnya untuk menambah asetnya baik aset lancar maupun tidak lancar.

Beberapa responden seperti responden 3,4, dan 5 menggunakannya untuk menambah kulakannya sehingga mampu melayani konsumen dengan jumlah yang lebih banyak, atau menambah variasi produknya sebagai rencana dalam jangka menengah untuk menambah jumlah pelanggan yang datang. Responden 6 menggunakan tambahan modalnya untuk menambah aset tidak lancarnya berupa mesin scanner. Responden 12 menggunakan pinjaman modalnya untuk melakukan renovasi atas aset tetapnya.

Adapun dua responden yang tidak mengalami peningkatan aset, keduanya merupakan responden yang tidak menggunakan pinjaman produktif dari BMT Asy Syifa untuk keperluan produktif. Responden 8 dan 10 menggunakan pinjaman modal yang didapatkannya untuk keperluan konsumtif seperti keperluan pendidikan anak atau keperluan barang-barang rumah tangga.

Peningkatan aset tersebut dapat dilihat sebagaimana tercantum dalam tabel 2 berikut: 
Tabel 2. Peningkatan pendapatan usaha (sebelum dan setelah menerima produk pembiayaan mudharabah mikro di BMT Asy Syifa Kabupaten Sidoarjo)

\begin{tabular}{|c|c|c|c|}
\hline In & Aset Sebelum & Aset Sesudah & Keterangan \\
\hline 3 & $30 \mathrm{~kg}$ per hari & $50 \mathrm{~kg}$ per hari & Meningkat \\
\hline 4 & $\begin{array}{ll}\text { Menu } & \text { kopi } \\
\text { dan teh } & \end{array}$ & $\begin{array}{l}\text { Menu makanan } \\
\text { bertambah }\end{array}$ & Meningkat \\
\hline 5 & $\begin{array}{l}\text { Menu nasi } \\
\text { penyetan }\end{array}$ & $\begin{array}{l}\text { Menu } \\
\text { bertambah } \\
\text { rawon }\end{array}$ & Meningkat \\
\hline 6 & $\begin{array}{l}\text { Alat sablon } \\
\text { dan } \\
\text { percetakan }\end{array}$ & $\begin{array}{l}\text { Bertambah } \\
\text { kabel dan cat }\end{array}$ & Meningkat \\
\hline 7 & $\begin{array}{l}\text { Kopi dan } \\
\text { minuman } \\
\text { sachet }\end{array}$ & $\begin{array}{l}\text { Merk dan jenis } \\
\text { minuman } \\
\text { bertambah }\end{array}$ & Meningkat \\
\hline 8 & $\begin{array}{l}\text { Ayam potong } \\
\text { dan } \\
\text { rombongnya }\end{array}$ & $\begin{array}{l}\text { Ayam potong } \\
\text { dan } \\
\text { rombongnya }\end{array}$ & Tetap \\
\hline 9 & $\begin{array}{l}\text { Alat dan } \\
\text { bahan } \\
\text { pembuat kue }\end{array}$ & $\begin{array}{l}\text { Bertambah } \\
\text { makanan } \\
\text { ringan }\end{array}$ & Meningkat \\
\hline 10 & $\begin{array}{l}\text { Bahan } \\
\text { gorengan dan } \\
\text { soto }\end{array}$ & $\begin{array}{l}\text { Bahan } \\
\text { gorengan dan } \\
\text { soto }\end{array}$ & Tetap \\
\hline 11 & Sembako & $\begin{array}{l}\text { Penambahan } \\
\text { kuantitas } \\
\text { sembako }\end{array}$ & Meningkat \\
\hline 12 & 26 kamar kos & $\begin{array}{l}5 \quad \text { kamar } \\
\text { renovasi }\end{array}$ & Meningkat \\
\hline
\end{tabular}

2. Omzet Usaha

Menurut Chaniago (1995:14) omzet penjualan adalah keseluruhan jumlah pendapatan yang didapat dari hasil penjualan suatu barang atau jasa dalam kurun waktu tertentu. Sehingga omzet penjualan dapat diartikan sebagai keseluruhan jumlah penjualan barang atau jasa dalam kurun waktu tertentu, yang dihitung berdasarkan jumlah uang yang diperoleh.

Omzet penjualan usaha berarti menunjukkan volume penjualan suatu usaha dalam jangka waktu tertentu, dan peningkatan terhadap pesanan memberikan kesempatan untuk terlunasinya seluruh kewajiban dan kemampuan bagi usaha-usaha yang bersangkutan untuk menjaga aliran kasnya tetap berjalan. Peningkatan laba kesepuluh responden tersebut dapat digambarkan dalam grafik sebagaimana terlihat dalam gambar 1 . berikut:

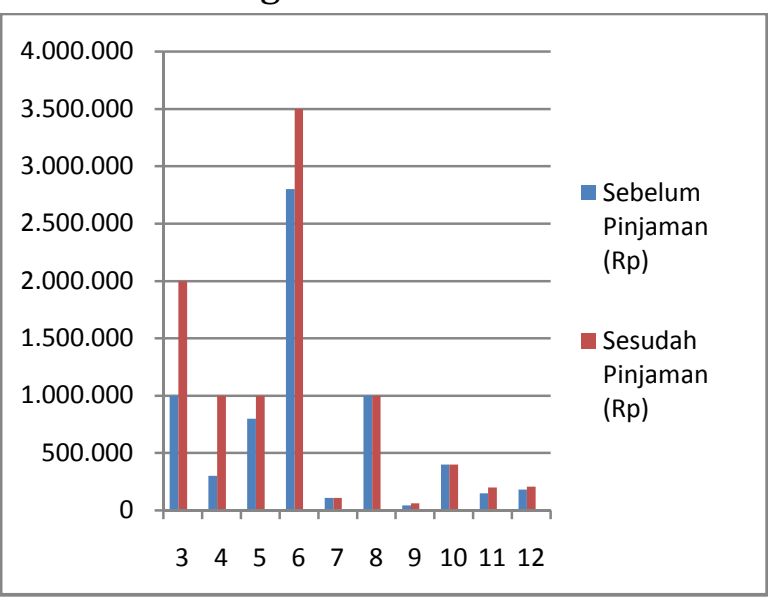

Gambar 1.

Grafik peningkatan omzet responden (sebelum dan setelah menerima produk pembiayaan mudharabah mikro di BMT Asy Syifa Kabupaten Sidoarjo)

Dari 10 responden, 7 responden mengalami peningkatan usaha jika dilihat dari omzet, tiga responden mengalami stagnansi dimana omzet usaha mereka tidak mengalami peningkatan baik sebelum dan sesudah respondenresponden tersebut mendapatkan pembiayaan mudharabah mikro dari BMT Asy Syifa.

Rata-rata responden mengalami peningkatan omzet. Tiga responden yang tidak mengalami peningkatan omzet adalah responden 7,8 , dan 10 . Responden 7 tidak mengalami peningkatan usaha karena lokasi usahanya yang tidak strategis dan terlalu bergantung pada ramai dan sepinya pengunjung tanpa ada usaha untuk menarik lebih banyak pengunjung. Sedangkan responden 8 dan 10 tidak mengalami peningkatan omzet 
karena menggunakan dana pinjamannya untuk keperluan konsumtif.

3. Pendapatan Usaha

Pendapatan didefinisikan Sholihin (2010: 621) sebagai suatu kenaikan kotor dalam aset atau penurunan dalam liabilitas atau gabungan keduanya selama periode tertentu yang diperoleh dari investasi, jasa, perdagangan, atau aktivitas lain yang halal dan bertujuan untuk meraih keuntungan. Pendapatan usaha terkait dengan laba atau rugi, tergantung dari selisih antara revenue dengan cost dari usaha yang bersangkutan.

Dari kesepuluh responden yang diwawancarai oleh peneliti, 7 responden mengatakan bahwa terjadi kenaikan pendapatan atau laba terhadap usaha mereka sementara tiga responden tidak mengalaminya. Dengan kata lain tiga responden tersebut tidak mengalami peningkatan laba baik sebelum dan sesudah responden-responden tersebut mendapatkan pembiayaan mudharabah mikro dari BMT Asy Syifa.

Tidak meningkatnya laba dari ketiga responden tersebut tidak lain disebabkan omzet mereka juga tidak mengalami peningkatan setelah melakukan pinjaman mudharabah mikro. Peningkatan laba kesepuluh responden tersebut dapat digambarkan dalam grafik sebagaimana terlihat dalam gambar 2 berikut.

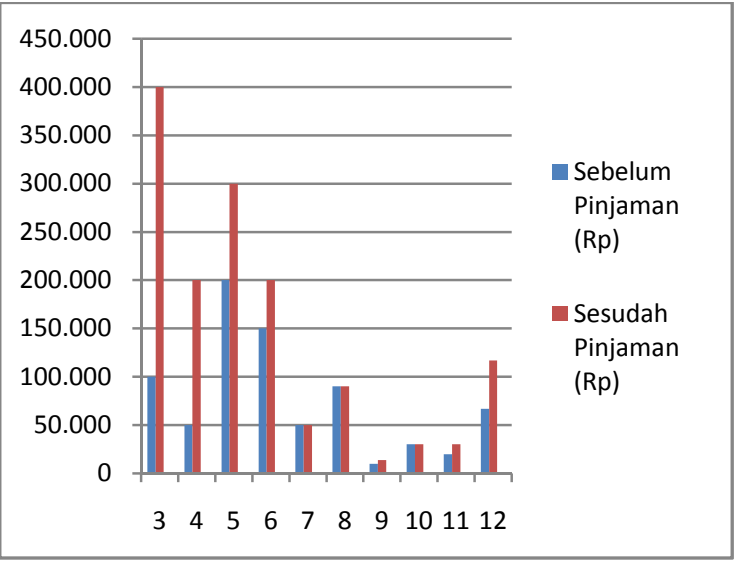

Gambar 2

Grafik peningkatan pendapatan usaha responden

(sebelum dan setelah menerima produk pembiayaan mudharabah mikro di BMT

Asy Syifa Kabupaten Sidoarjo)

Responden yang tidak mengalami kenaikan usaha dari sisi pendapatan adalah responden 7,8 dan 10. Sama seperti yang terjadi pada kenaikan omzet, responden 8 dan 10 tidak menggunakan modal pinjaman mudharabah mikro dari BMT Asy Syifa untuk keperluan produktif. Responden 8 dan 10 lebih banyak menggunakan dana tersebut untuk keperluan konsumtif. Sementara responden 7 tidak mampu menarik pelanggan lebih banyak selain pelangganpelanggan yang telah ada.

4. Stabilitas Usaha

Munawir (2000: 31) mengartikan stabilitas usaha sebagai kemampuan perusahaan untuk melakukan usahanya dengan stabil, yang diukur dengan mempertimbangkan kemampuan perusahaan untuk membayar kewajiban atas hutang-hutangnya termasuk tepat pada waktunya serta kemampuan menjalankan usahanya secara berkelanjutan tanpa mengalami hambatan atau krisis keuangan. 
Dalam penelitian ini, stabilitas usaha diartikan sebagai kemampuan suatu UMK dalam mempertahankan usahanya agar tetap berjalan dengan baik. Selama suatu usaha dapat berjalan tanpa berhenti dalam jangka waktu dua tahun, atau tidak mengalami sepi pengunjung dalam jangka waktu yang lama (kurang lebih satu minggu) maka suatu usaha dapat dikatakan stabil. Perbandingan stabilitas usaha 10 responden sebelum dan sesudah menerima pinjaman mudharabah mikro dapat dilihat dalam tabel 3 .

\section{Tabel 3}

perubahan stabilitas usaha responden (sebelum dan setelah menerima produk pembiayaan mudharabah mikro di BMT Asy Syifa Kabupaten Sidoarjo)

\begin{tabular}{|l|l|l|ll|}
\hline Res. & $\begin{array}{l}\text { Kondisi } \\
\text { Sebelum }\end{array}$ & $\begin{array}{l}\text { Kondisi } \\
\text { Sesudah }\end{array}$ & \multicolumn{2}{|l|}{ Keterangan } \\
\hline 3 & Stabil & $\begin{array}{l}\text { Lebih } \\
\text { Stabil }\end{array}$ & $\begin{array}{l}\text { Usaha } \\
\text { Stabil }\end{array}$ & Lebih \\
\hline 4 & Stabil & $\begin{array}{l}\text { Lebih } \\
\text { Stabil }\end{array}$ & $\begin{array}{l}\text { Usaha } \\
\text { Stabil }\end{array}$ & Lebih \\
\hline 5 & Stabil & Stabil & $\begin{array}{l}\text { Usaha } \\
\text { Stabil }\end{array}$ & Tetap \\
\hline 6 & Stabil & Stabil & $\begin{array}{l}\text { Usaha } \\
\text { Stabil }\end{array}$ & Tetap \\
\hline 7 & Stabil & Stabil & $\begin{array}{l}\text { Usaha } \\
\text { Stabil }\end{array}$ & Tetap \\
\hline 8 & Stabil & Stabil & $\begin{array}{l}\text { Usaha } \\
\text { Stabil }\end{array}$ & Tetap \\
\hline 9 & $\begin{array}{l}\text { Tidak } \\
\text { Stabil }\end{array}$ & $\begin{array}{l}\text { Kurang } \\
\text { Stabil }\end{array}$ & $\begin{array}{l}\text { Usaha } \\
\text { Stabil }\end{array}$ & Lebih \\
\hline 10 & $\begin{array}{l}\text { Tidak } \\
\text { Stabil }\end{array}$ & $\begin{array}{l}\text { Tidak } \\
\text { Stabil }\end{array}$ & $\begin{array}{l}\text { Usaha } \\
\text { Stabil }\end{array}$ & Tidak \\
\hline 11 & Stabil & Stabil & $\begin{array}{l}\text { Usaha } \\
\text { Stabil }\end{array}$ & Tetap \\
\hline 12 & Stabil & $\begin{array}{l}\text { Lebih } \\
\text { Stabil }\end{array}$ & $\begin{array}{l}\text { Usaha } \\
\text { Stabil }\end{array}$ & Lebih \\
\hline & & & & \\
\hline
\end{tabular}

Dari kesepuluh responden yang diwawancarai oleh peneliti, 5 responden memiliki usaha yang tetap stabil. Terdapat 3 responden yang mengalami kenaikan kondisi dari stabil menjadi lebih stabil dikarenakan kenaikan omzet dan laba yang sangat signifikan pada usahanya. Satu responden mengalami kenaikan kondisi dari tidak stabil menjadi kurang stabil, dikarenakan responden yang masih bergantung pada pesanan yang sangat jarang datang. Dan satu responden usahanya tidak stabil. Alasan ketidak stabilan tersebut adalah pemilik usaha yang harus berkali-kali menghentikan usahanya dengan menggunakan uang omzetnya untuk keperluan konsumtif, sehingga perputaran kasnya terhenti dan usaha tersebut tidak mampu dijalankan kembali.

Dalam meningkatkan usaha mikro nasabahnya, BMT Asy Syifa memiliki dua peranan penting bagi nasabahnya. Dua peranan tersebut adalah peran pembiayaan dan peran pendampingan. Pembiayaan penting dalam peranannya memberikan bantual modal bagi pemilik usaha mikro untuk semakin meningkatkan usahanya. Dan pendampingan juga memiliki perannya tersendiri untuk memberikan bantuan secara ilmu maupun moral agar pemilik usaha mikro mampu menjalankan usahanya dengan lebih baik.

Peningkatan pada aset, omzet, dan pendapatan menjadi pemicu untuk meningkatkan stabilitas dari usaha. Pemilik usaha semakin mampu menjaga stabilitas omzet dan pendapatannya tanpa terlalu sering mengalami kerugian. Peningkatan pada omzet juga membantu pemilik usaha untuk melunasi kewajibannya tanpa hambatan. Dapat disimpulkan bahwa pembiayaan mudharabah mikro memang mampu meningkatkan usaha mikro dalam batasan-batasan tertentu saja. Peningkatan usaha tersebut bukanlah 
peningkatan usaha yang terjadi secara signifikan dalam waktu singkat setelah mendapatkan modal pinjaman. Peningkatan usaha tersebut terjadi secara bertahap, yang dalam penelitian ini masih terbatas pada kemampuan bagi usaha mikro untuk menambah asetnya, menarik konsumen baru (menambah jumlah konsumen), meningkatkan omzet dan pendapatannya (secara rata-rata, baik signifikan ataupun tidak), serta membantu pemilik usaha mampu melunasi kewajibannya secara tepat waktu tanpa hambatan.

\section{KESIMPULAN DAN IMPLIKASI}

Baitul Maal wat Tamwil telah menunjukkan perannya dalam peningkatan usaha mikro melalui akad mudharabah yang diwakili oleh produk pembiayaan mudharabah mikro. Peran tersebut dapat dilihat pada peningkatan usaha responden yang dilihat dari empat aspek yaitu peningkatan pada aset, omzet, pendapatan, serta stabilitas usaha. Hal tersebut tidak terjadi pada semua usaha mikro yang mendapatkan produk pembiayaan tersebut.

\section{DAFTAR PUSTAKA}

Bungin, M. Burhan. 2005. Penelitian Kualitatif: Komunikasi, Ekonomi, Kebijakan Publik, dan Ilmu Sosial Lainnya. Jakarta: Kencana Prenada Media Group.

Chaniago, Arifinal dkk. 1995. Ekonomi 2. Bandung: Angkasa

Diola, Alfa. 2011. Peran BMT dalam Meningkatkan Kesejahteraan Anggota pada BMT-UGT Sidogiri Surabaya. Skripsi tidak diterbitkan. Fakultas Ekonomi dan Bisnis, Universitas Airlangga Surabaya.
Falihah, Ety Ihda. 2007. Peran Baitul Maal Wat Tamwil dalam Upaya Pemberdayaan Usaha Mikro pada BMT-MMU kraton Sidogiri Pasuruan. Skripsi tidak diterbitkan. Fakultas Ekonomi, Universitas Negeri Islam Malang.

Hidayat, Mohamad. 2010. An Introduction to the Sharia Economic. Jakarta: Zikrul Hakim.

Huda, Nurul \& Mohamad Heykal. 2010. Lembaga Keuangan Islam, Tinjauan Teoritis dan Praktis. Jakarta: Kencana

Ikatan Akuntan Indonesia. 2002. PSAK No.59 Pernyataan Standar Akuntansi Keuangan. Jakarta: Dewan Standar Akuntansi Keuangan.

Karim, Adiwarman. 2011. Bank Islam, Analisis Fiqh dan Keuangan. Jakarta: Raja Grafindo Persada.

Khaeli, Dhita Normaliza. 2012. Peran Pembiayaan dalam Peningkatan Kemampuan Konsumsi Anggota Baitut Tamwil Muhammadiyah di Kabupaten Jombang. Skripsi tidak diterbitkan. Fakultas Ekonomi dan Bisnis, Universitas Airlangga Surabaya.

Moleong, Lexy.J. 2006. Metode Penelitian Kualitatif. Bandung: Remaja Rosdakarya.

Muhammad. 2000. Lembaga-Lembaga Keuangan Umat Kontemporer. Yogyakarta: UII Press

Munawir. 2010. Analisis Laporan Keuangan, Edisi Keempat. Yogyakarta: Liberty

Nazir, Muhammad. 2005. Metode Penelitian. Bogor: Ghalia Indonesia.

Rahmi, Nadia Puspa. 2011. Peran Pembiayaan Mudharabah dan Murabahah dalam Pemberdayaan 
Usaha Mikro dan Kecil pada BMT Nurul Jannah Gresik. Skripsi tidak diterbitkan. Fakultas Ekonomi dan Bisnis. Universitas Airlangga, Surabaya.

Sholihin, Ahmad Ifham. 2010. Buku Pintar Ekonomi Syariah. Jakarta: Gramedia.

Suhendri. 2011. Manajemen Qardhul Hasan dalam Pembiayaan Usaha Kecil Menengah di BAZ Kota Depok. Skripsi tidak diterbitkan. Fakultas Ilmu Dakwah dan Komunikasi. Universitas Islam Negeri, Jakarta.

Syafi'i, Muhammad Antonio. 2009. Bank Syariah, Dari Teori ke Praktek. Depok: Gema Insani.

Yin, Robert K. 2012. Studi Kasus, Desain dan Metode. Jakarta: Raja Grafindo Persada. 
